\title{
The Prototype Model of Asymmetric Decentralization in Providing Public Services to the Island Areas
}

\author{
Jusuf Madubun \\ Haedar Akib \\ Jasruddin \\ Department of Public Administration of Universitas Negeri Makassar, \\ Jin. Bonto Langkasa Kampus Gunung Sari Baru, Makassar, South Sulawesi, Indonesia \\ Email: m.yusuf2431@yahoo.com, haedar652002@yahoo.com, mahande64@yahoo.com
}

Doi:10.5901/mjss.2017.v8n2p209

\begin{abstract}
This study aims at identifying the main obstacles to optimizing the provision of public services to the districts in the island areas and to discussing the prototype model of asymmetric decentralization in providing public services to the island areas. This study was conducted in three districts of small islands at the Tual city of Maluku province namely the districts of Kur Island, South Kur Island, and Tayando Tam island. The data were collected through triangulation of sources and methods. The informants were selected based on consideration of the position and competence of the required information. The methods were the in-depth interview, observation, documentation, and the Focus Group Discussion (FGD). The results showed that there were three main obstacles in providing public services to the districts in the island areas. Firstly, the partial authority of Mayor of Tual city had not given yet to the Head of Districts based on the Article 226 of Law No. 23 in 2014 about Regional Government. Secondly, the transportation for the islands was inadequacy and the natural conditions were challenging that obstructed the mobility of citizens to access the service center and it was difficult for officers to reach people who want to be served. Thirdly, the lack of resources (human resources, funds, and facilities) in some districts at the island areas. To overcome those problems, specific autonomous was required by island province that concerned different treatment settings to the districts within the island areas namely the expansion of authority, the increase in the position, and the development of resources and the organizational capacity and districts management.
\end{abstract}

Keywords: Asymmetric Decentralization, Public Services, and island areas.

\section{Introduction}

In the development of the modern country today, especially in emerging countries, public administration (public services) is one of the basic functions of government other than empowerment, development, and the setting (regulator). Public services can be interpreted as the government or public service agencies to fulfill basic human needs in the form of goods and services for their survival. In reality, basic needs may vary according to time and space. Thus, the efforts to fulfill the basic needs need approaches and different ways based on the conditions.

The geographical condition of Indonesia as an archipelagic country, two-thirds of its territory is the Ocean that consists of coasts, seas, bays, and straits. The coast has $95181 \mathrm{~km}$ long with 5.8 million km2 water area (Siombo, 2010, p. 1). Indonesia has more than 17,000 islands with a diversity of ethnic, religious and cultural. The physical characteristics of the geographic and demographic required a different touch by the Government, in this case, the public administration in carrying out its functions, especially public service.

As an island province, Maluku has 1340 islands with the extent of the sea is approximately 93\%. The geographical conditions gave many advantages such as the potential of natural resource of biological and non-biological marine, various types of flora and fauna that were typical of each island and also vulnerability, and the main potential was the effects of global climate change. If these conditions were not anticipated and managed well, there would be a serious impact on survival. 


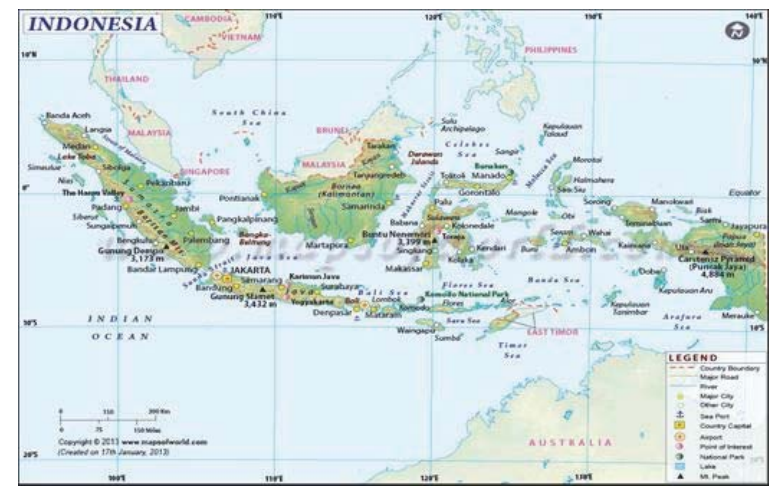

Figure 1. The map of Indonesia

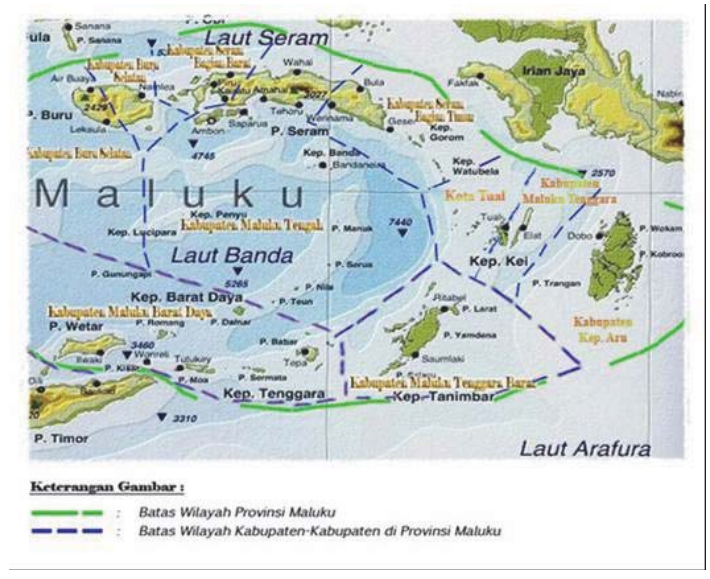

Figure 2. The map of Maluku Islands

Vulnerability conditions of small islands gave negative effects to the dynamics of government. In other words, such conditions inhibited the implementation of government, development, and public service. Whatever the weather is and how far the distance between the District and the Capital District/City is, and though the tools and infrastructure of transportation were inadequate. Those were certainly determinant factors that undermined the optimization of public services in areas of the islands. For island areas, those problems indicated that the intention of granting regional autonomy that was emphasized on district/city to introduce public service to the community was still unanswered.

This paper aimed to show how the constraints faced by the government at the district level in the Islands (small islands) at Tual city of Maluku province. In this case, how the government provided public service and discussed an alternative solution with approach or dimension of environmental public administration. The services were in the form of asymmetric decentralization to optimize public services in the islands.

\section{Review of Literature}

\subsection{The concept of Decentralization and Asymmetric Decentralization}

According to Cheema and Rondinelli (2007, p. 1) "Decentralization was defined as the transfer of authority, responsibility, and resources - through deconcentration, delegation, or Devolution - from the center to lower levels of administration" Decentralisation was a concept that is rather complex, so we need to describe it more broadly. Decentralization was not only developed in an environment organization or the activities of government institutions but also had been widely 
defined as the non-governmental organization. Rondinelli (1983, p. 188-189) explained the concept of decentralization in four categories. The first is deconcentration that involves the transfer of functions within the central government hierarchy through the shifting of workloads from the central ministries to field officers, the creation of field agencies, or the shifting of responsibility to local government administrative structure units. The second is delegation that involves the transfer of functions to regional or functional development authorities, parasternal organizations, or special project implementation units that often, operate free of central government regulations concerning personnel recruitment, contracting, budgeting, procurement and other matters, and that for the state in performing the prescribed functions with the ultimate responsibility for them remaining with the central government. The third is devolution that involves the transfer of functions or decision-making authority to legally incorporated local Governments, such as states, provinces, districts or municipalities. The fourth is transfer to non-government institutions that involves shifting responsibilities for activities from the public not part of the government structure.

Furthermore, according to White (2011, p. 2-3) "Types of decentralization are then further categorized as political, administrative, or fiscal. Political decentralization is defined as the extent to which political institutions track and collect citizen interests and turn them into policy decisions. Administrative decentralization concerns the ways in which political institutions turn policy decisions into allocated outcomes through fiscal and regulatory actions. Fiscal decentralization regards the extent to which local entities collect taxes, undertake expenditures, and rectify imbalances.

The environment of Indonesia is varied. Thus the most appropriate adaptation to the environment is to implement a decentralized system of government to be more able to accommodate a variety of problems, potentials, opportunities and constraints at the local level. Thus, not only public administration in Indonesia that differs from the public administration in Malaysia, Thailand, Philippines and so on, but also between the provinces, regencies or cities (Keban, 2008, p. 182). This fact was conceived as a middle way of decentralization that is intended to bridge the differences and uniqueness within a sovereign state and the area that is called asymmetric decentralization.

Asymmetric decentralization is a form of decentralization that was developed from the concept of decentralization itself, to distinguish it from the symmetrical decentralization that has been in force in various countries. The concept of asymmetric decentralization developed from the concept of asymmetric federalism that was first introduced by Tarlton. In his speech, Tarlton $(1965$, p. 1) states that "Two concepts, both to be explored in greater detail in a later section, can be introduced and their general content suggested here. The first, the notion of symmetry refers to the extent to which component states share in the conditions and thereby the concerns more or less common to the federal system as a whole. By the same token, the second term, the concept of asymmetry expresses the extent to which component states do not share these common features. Whether the relationship of a state is symmetrical or asymmetrical is a question of its participation in the pattern of social, cultural, economic, and political characteristics of the federal system of which it is the part. This relation, in turn, is a significant factor in shaping its relations with other component states and with the national authority." According to Congleton (2006, p. 5), "Asymmetric federalism exists whenever governments at the same level of geographic responsibility-towns, counties, cities, or states-have different regulatory and fiscal powers." In treating a pluralistic society with a uniform approach was a mistake that should not happen. As stated by Katorobo (2007, p. 245), that "literature review of decentralization of many countries leads to the conclusion that asymmetric decentralization is more effective than symmetric decentralization. From the theoretical standpoint, all ideas about government decentralization to sub-national units are decentralized design errors that lead to the improper transfer of functions that the units cannot do."

In relation to the opinion above, Veljanovski, $(2010$, p. 3) describes three types of asymmetric decentralization concept as follows; "... several types of asymmetry could be identified while defining the relations between the central and the local authorities: political asymmetry, which is applied mainly for non-economic and political reasons in countries where there are local units with different capacities or where there are local units with different responsibility assignments; administrative asymmetry achieved with an agreement between the central and local authorities where the competencies are agreed considering the administrative capacities of the local authorities; and fiscal asymmetry in the light of the two previous models followed by their financial dimension. In other words, the asymmetry might be de jure or de facto, or it might be implemented on the entire territory or only on a specific part, where there is a need, as for instance in Spain and Canada.

While, the understanding of asymmetry concept of de jure and de facto, Watts $(2005$, p. 2) writes that "The former refers to asymmetry embedded in constitutional and legal processes, where constituent units are treated differently under the law. The latter, de facto asymmetry, refers to the actual practices or relationships arising from the impact of cultural, social and economic differences among constituent units within a federation, and as Tarlton noted is typical of relations within virtually all federations. De jure asymmetry may refer to relations among full-fledged constituent units, to differences between full-fledged constituent units and peripheral constituent units (e.g. territories, federacies and 
associated states), and may be transitional (i.e. eventual uniformity achieved at 'varying speeds') or permanent (i.e. viewed as 'variable geometry')."

The implementation of asymmetric decentralization at the federal or in a unitary state was certainly intended to provide more benefits to the improvement of public services. According to Huda (2014, p. 72), "the ultimate goal of asymmetric decentralization is the make sure a region can run the core functions of government well within the specified standards." Thus, asymmetric decentralization is the practice of decentralization that gives the possibility of differences in treatment between an area or several areas with another area in a country because of the uniqueness in historical factors, the political, economic, or physical condition of the geographical territory. Thus, the policy of asymmetric decentralization did not intend to establish a state within the state, but as a framework solution for differentness and the interests of national unity and integration of a pluralistic nation.

\subsection{Environmental Dimension of Public Administration: Toward a Regional Asymmetric Decentralization Islands}

Biological experts prove that living organisms cannot escape from dependency and interaction to the environment, both physical and biological itself. Even the organisms reach a point of balance (equilibrium) in the life cycle when the interaction with the environment is also to the point of being balanced. When the organism destroyed nature and environment, then the affliction and the organism would be imbalance. Even if the organism is not able to adapt themselves to the environment that is dramatically changed, the life cycle can be ended. This means that an organism's survival may depend on the quality of mutual interaction with the environment wherever it is located.

That awareness led to a new approach in the branch of biology that was known as Ecological Approach. According to Webster's Dictionary, Ecology is the branch of biology concerning the relationship between the survivals with the organisms around (Syafiie, 1998, p. 2). Then an ecological approach tried to be developed in many other branches of science; we also know the ecology branch of government and administration.

Ecological administration approach tried to examine how the interplay between the environment and the ongoing administration practices in governmental organization and also non-state sector that carry out the public mission. According to Robins (1991) in Keban (2008, p. 181), "the dynamics or changes in the internal dimension of public administration such as policy, management, organization, morals or ethics, and performance in the public administration are strongly influenced by external dimension of public administration items, namely the environment. The importance of environmental influences was recognized since the existence of concept and theory about administration and organization ecology or since F.E. Emery identified the concept "open system." Furthermore, Keban (2008, p. 184) explained that" Paradigm "open system" describes the interaction that was so intense between an organization and its environment, so what the organization did was so dictated by the environment. It is clear that the environmental conditions determined the existence and development of an organization. Recently, public organization is always required to respond to the needs, aspirations, and problems faced by the surrounding community, it means that the paradigm of an open system should be adopted. "

Therefore, the characteristic was necessary to be owned by an area, including the physical environment of the geographical as a determinant that affected the optimization of public services. In contextualization framework of decentralized governance theory, the reality of Indonesia characters needed implementation of asymmetric decentralization as an ice-breaker barriers of public services that were occurred during this time in the island areas.

\section{Methods}

This study took place in five districts in the work area of Tual City, namely the district of South Dullah, North Dullah, Kur Islands and South Kur. This study as shown in Figure3, the method was qualitative method. Data were collected through a process of triangulation namely interview, observation and documentation, and also the Focus Group Discussion (FGD).

The writer had interviewed some key informants namely Secretary of Tual City, some bureaucrats, the Head of sub-district and village, and community leaders. While, FGD involved the Head of the sub-district and village from the district of the islands. 


\section{Results and Discussion}

\subsection{Public Service at Tual City: Existing Condition}

Tual City is one of 11 Regencies / Cities in Maluku province. The Tual city was carved out of the Southeast Maluku district in 2007 under the Act (UU) No. 31 in 2007 about the Establishment of Tual City in Maluku Province. Geographically, Tual City is a city of islands (city of small islands) that consists of a cluster of small islands called as the cluster of Kei Islands. The tual city has 66 islands that spread between the Banda Sea and the Arafura Sea.

Tual City administratively consists of five districts namely the District of South Dullah, North Dullah, Tayando Tam, and South Islands of Kur Kur. Three districts of the latter is an archipelago of districts that spread across three separate islands from the capital city of Tual, as shown in Figure 3.

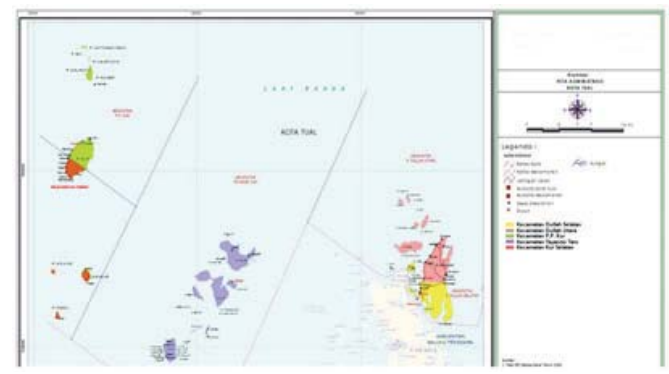

Figure 3. The administration map of Tual City

The overall area of the Tual City is approximately $19.342 .39 \mathrm{~km} 2$ with a land area of $254.39 \mathrm{~km} 2$ and spacious waters reached approximately 19.088 square kilometers. In other words, Waters area of Tual City was $98.69 \%$ if it was compared to its land area. Table 1 illustrates the area specified by the district with the distance to the capital city of Tual.

Table 1. The extent and distance to Tual city based on the District

\begin{tabular}{clcccc}
\hline \multirow{2}{*}{ No } & \multirow{2}{*}{ District } & \multicolumn{2}{c}{ extent $\left(\mathrm{Km}^{2}\right)$} & \multicolumn{2}{c}{ Distance to Tual city } \\
\cline { 3 - 5 } & & Land & waters $^{* *}$ & Km & Miles of sea \\
\hline 1 & Kur Islands* & 34,50 & & 103 & 57 \\
2 & South Kur* & 27,98 & & 103 & 57 \\
3 & Tayando Tam* & 69,07 & 45,42 & 24,53 \\
4 & North Dullah & 70,85 & & 9,09 & 4,91 \\
5 & South Dullah & 51,99 & & 0 & 0 \\
\hline & & 254,39 & 19.088 & - & - \\
\hline
\end{tabular}

*districts of islands; ${ }^{* *}$ the data based on district is unavailable

Source: Compilation of Tual in numbers, 2015, page 3 and 10, and each district in numbers, 2015.

With a wide geographical, physical condition and the mileage that was quite far from the islands to the Capital District of Tual accompanied transport constraints, the public service will experience many obstacles. Images of public services at the sub-district in the city of Tual islands that occurred during this time, it was still very alarming and characterized in three things. The first thing was the difficulty and the high cost of access to reach public service centers. Population administration services such as the maintenance of family card, ID card, deed and description of other residents, through the Department of Population and civilians who resided in the Tual city. The people must provide funds for transportation and accommodation during the waiting period, either in waiting for the completion of the technical management of the institution in question and in awaiting the boat to return to their areas. Thus, a business requires a high cost and a long time. The second thing was sub-district coordination function was often not running because ego sectoral / resistances of services / technical institution that caused many programs/projects were misdirected even fail. The officers handled directly without well coordination with the Head, but the Head was the one who better understands the characteristics and fundamental problems in their communities. The last thing was the availability of resources in districts that was not yet 
sufficient, as a consequence of limited authority. Some basic services such as education and health, the obstacles also encountered quite serious. One of them was the disparity in the distribution of teachers between the districts of islands with the mainland as shown in Table 2. In addition, the aspect of education like facilities was inadequate.

Table 2. The Total of Schools, Classrooms, Teachers and Students Based on the Districts in Tual city

\begin{tabular}{|c|c|c|c|c|c|c|c|c|c|}
\hline \multirow{2}{*}{ No } & \multirow{2}{*}{ District } & \multicolumn{2}{|c|}{ Total of schools } & \multicolumn{2}{|c|}{ Total of Classrooms } & \multicolumn{2}{|c|}{ Total of teacher } & \multicolumn{2}{|c|}{ Total of Students } \\
\hline & & SD/MI & SMP/MTs & SD/MI & SMP/MTs & SD/MI & SMP/MTs & SD/MI & SMP/MTs \\
\hline 1 & Kur Islands & 4 & 1 & 24 & 3 & 37 & 7 & 504 & 81 \\
\hline 2 & South Kur & 6 & 3 & 36 & 12 & 52 & 36 & 1408 & 275 \\
\hline 3 & Tayando Tam & 8 & 3 & 48 & 16 & 87 & 37 & 1008 & 354 \\
\hline 4 & North Dullah & 10 & 7 & 78 & 54 & 142 & 89 & 1890 & 781 \\
\hline 5 & South Dullah & 22 & 5 & 170 & 82 & 211 & 111 & 4535 & 1807 \\
\hline \multicolumn{2}{|c|}{ Total } & 50 & 19 & 356 & 167 & 529 & 280 & 9345 & 3298 \\
\hline
\end{tabular}

Data Source: Kantor Dinas Pendidikan Pemuda dan Olah Raga Kota Tual, July 2016

From the data in Table 2, if it was compared to the total of teachers per school in the district of the islands and the mainland, the islands look to the sub-district average on SD / MI there were only ten teachers for each school, and for SMP / MTs there were 11 teachers per school. Meanwhile, in the mainland districts for SD / MI there were 12 teachers per school, and for SMP / MTs there were 18 teachers per school. If it was explored further, for SMP / MTs in the district of the islands was still a vacancy occurred for a particular field of study, such as Biology, History, Economics, Mathematics, Arts and Culture, and Physical and Sports Education.

The same condition was also found in the areas of health. The first was the lack of practitioners in the city of Tual and disparities number of doctors and other medical personnel between districts islands with the mainland. The second was infrastructure for health like Puskesmas (Community Health Center), PUSTU (Alternative Puskesmas), medical equipment facilities and the availability of medicines were inadequate. Images of these conditions adversely affect the optimization of public services in the health sector in the district of islands.

If it was observed carefully, the data in Table 3 and 4 showed that the number of practitioners in the district of the island and Tual city was still very minimal. With a population of 83.621 inhabitants, seven general practitioners may not be able to serve the people's health at Tual city adequately. Similarly, the health facilities such as hospitals, health center, and sub-health center both regarding quantity and facilities were inadequate.

Table 3. Practitioners and Medical personnel at Tual City

\begin{tabular}{llccccc}
\hline & & \multicolumn{5}{c}{ Tenaga Kesehatan } \\
\cline { 2 - 6 } & District & General practitioners & Dentist & General Nurse & Midwives & Sanitary \\
\hline 1 & Kur Islands & - & - & 11 & 10 & 1 \\
2 & South Kur & - & - & 10 & 9 & - \\
3 & Tayando Tam & - & - & 15 & 1 & - \\
4 & North Dullah & 3 & - & 75 & 34 & 4 \\
5 & South Dullah & 4 & 2 & 51 & 26 & 4 \\
\hline & Total & 7 & 2 & 162 & 80 & 9 \\
\hline
\end{tabular}

Sources: Ministry of Health, Tual city, July 2016.

Tabel 4. Public Health Facilities at Tual city

\begin{tabular}{clccccc}
\hline & & \multicolumn{5}{c}{ Jenis Fasilitas Kesehatan } \\
\cline { 2 - 6 } No & Kecamatan & Rumah Sakit & Puskesmas & Pustu & Klinik & Posyandu \\
\hline 1 & P.P Kur & - & 2 & - & - & 8 \\
2 & Kur Selatan & - & 2 & 1 & - & 10 \\
3 & Tayando Tam & - & 3 & 1 & - & 11 \\
4 & Dullah Utara & 1 & 5 & 1 & - & 30 \\
5 & Dullah Selatan & - & 3 & 1 & 2 & 34 \\
\hline & Total & $\mathbf{1}$ & $\mathbf{1 5}$ & $\mathbf{4}$ & $\mathbf{2}$ & $\mathbf{9 3}$ \\
\hline
\end{tabular}

Sources: Ministry of Health, Tual July 2016 
Supposedly, the problems above can be minimized if the Mayor wants to share the responsibility with the Head of the district based on the regulations. On the Law No. 23 in 2014, the delegation had been set up the responsibility of the mayor that could be shared with the head of the district. Paragraph 1 stated that "Besides to implement the tasks as referred in Article 225 paragraph 1, the Head of District obtained partial delegation of regent / mayor to carry out Government Affairs under the authority of districts / cities." Paragraph 2 stated that "The delegation of regent / mayor as referred in paragraph 1 should be based on the map of public services and based on the characteristics of the district and needs of society in sub-districts." Paragraph 3 stated that" The delegation of the authority of the regents/mayors as referred in paragraph 2 should be determined by the decision of the regent / mayor and guided by government regulations." However, those had not been implemented yet.

Supposedly, in sharing some authority was under the provisions of such normative, the transfer of functions, funds, human resources, and facilities was expected to happen to the district so that the districts would become the center of public services for the community. However, the normative provisions had not been implemented yet by the Mayor of Tual city. Thus the Head of District practically had no delegated authority. This condition occurred because the delegation was the subject of delegated authority of the political Mayor's will, but there was concern that if the authority were delegated, it would reduce the influence and popularity of the mayor himself, especially for the incumbent in the next election. Similar treatment to all districts both land and islands was based on the normative regulation and affected to hinder efforts to optimize public services and to hinder progress in improving the welfare of the communities in three districts of islands.

Based on the real complexity of the problems, then it was the turn of the public administration to rethink the ground approach for public services. In this case, the need for new approaches in the implementation of decentralization in Indonesia was better suited to environmental factors of the served society in particular the physical condition of the geographical factors of the Indonesia archipelago that was very diverse.

\subsection{Specific Autonomy of Islands Province: Solutions for asymmetric decentralization in Public Service}

A public policy that was made by the government aimed to solve various problems faced by the society as citizens. Thus, the policy of decentralization or asymmetric decentralization was a form of government efforts to solve public problems because the public services were not optimal yet in the islands.

Specific autonomy which has been practiced in Daerah Istimewa (DI) Nangroh Aceh Darussalam (NAD), DI Yogyakarta (DIY), Papua and Daerah Khusus Ibukota (DKI) Jakarta, and the province of Papua and West Papua. It was actually a manifestation of their implementation of asymmetric decentralization in the Republic of Indonesia (NKRI). It was also a solution to its specificity. The basic consideration for the application of asymmetric decentralization in all four areas was quite varied. Firstly, political dimension, locality and religious to NAD through Law No. 11 in 2006; that political dimensions were associated with the accommodation of the Central Government in reducing the desire to separate themselves (independent), and given the privilege to form local political parties as part of the contents of special autonomy. While, the religious dimension was marked with the contents of the special autonomy that allows the application of Islamic law in the land of Rencong. Secondly, the political-cultural dimension to Papua by Law No. 21 in 2001, and West Papua with Law No.21 in 2001 and also the Law No. 35 in 2008, those were related to political accommodation as compensation to the demands for independence. Cultural dimension could be seen in the role of the traditional figure in the Papua People's Assembly (MRP). Thirdly, historical-cultural dimension to the Daerah Istimewa Yogyakarta (DIY) by Law No. 13 in 2012 that was associated with the cultural reality where the kings of Java (Sri Sultan Hamengkubuwono and Sri Pakualaman) were culturally having the privilege - traditional authority - and was automatically appointed as the Governor and Deputy Governor of DIY. Fourthly, the historical-political dimension to Jakarta (Act No. 29 of 2007), to the historical-political aspect, Jakarta became an important struggle for independence and the Capital of the United States, Republic of Indonesia.

Reflecting on the various dimensions of considerations underlying the application of asymmetric decentralization to the four areas, it indicated that seven Islands Province (Maluku, North Maluku, North Sulawesi, East Nusa Tenggara, West Nusa Tenggara, Bangka Belitung and Riau Islands) should be given the specificity in governance, management development, and empowerment and public services. In regard to the focus of this paper, the factors or the physical dimensions of geographic condition should be served as a foundation strong consideration to implement a policy of affirmative (affirmative action) in the form of asymmetric decentralization as part of the solution to various environmental barriers to physical geography in an effort to optimize public services in the area Island. Geographic characteristics of various barrier islands and public services will put forward in the future. It must have become a strong justification for the central government to give specific autonomy for the islands. With the implementation of the different poor condition of 
public services in areas that were characterized by islands could be addressed adequately.

In order to optimize public services in the district of the island, so it takes the position and role of a strong and maximum districts, not merely as a working tool districts / cities as stipulated in Law No. 23 in 2014, which makes the Head of District just wait for mercy (political will) of the regent / mayor through the delegation of authority that was never materialized so far.

From the various realities above, it is time for Islands Province was given some kind of "specific autonomy" - which forms the setting sub-district that was distinguished from other regions (Regions Mainland) so that the Sub-district government had sufficient authority (autonomy) in managing the affairs of the vital, urgent and typical for the optimization of public services, and improving people's welfare. The framework of special autonomy offered Islands Province such as shown in Figure 4.

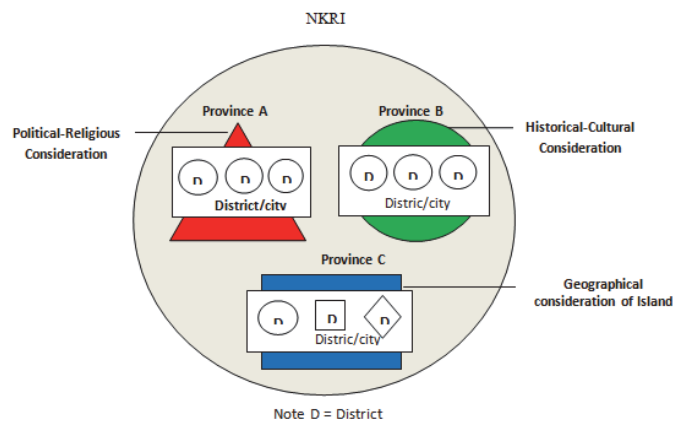

Figure 4. Asymmetric decentralization of Island Province in Indonesia

In other words, based on the perspective of the environmental dimension of public administration, to optimize public services in small islands, asymmetric decentralization based on the consideration of dimensional characteristics of the physical environment of geographical islands was necessary. In this context, substance or content of autonomy, in particular, was closely linked to the specificity of the position, authority, roles and functions of the wider archipelago districts to optimize public services. Through this policy, the District was expected in the islands had attributive and broad authority based on the arrangements and guarantees of Indonesian Law to overcome various obstacles in governance, development, and public services proportionally.

Five potential positive impacts could be realized with this model. Firstly, the tasks of districts/municipalities were reduced based on authority-owned, so the Regent / Mayor could concentrate on the one things and more strategically in the district/city level. Secondly, the capacity of the District and the competence of its institutions inevitably would also be improved. Thus districts would be a community service center. Thirdly, the distance that separated government services to the community so far could be overcome. Fourthly, the financial management system was based on the principle money follow function, and then by increasing the capacity of the duties and functions of the District, there would be an impact on the flow of funds to the district. Thus, the economic dynamics districts would grow. Lastly, Strengthen national integration, and avoid the appearance of a new autonomous region expansion demands (DOB), which in reality during this required energy and greater resources.

\section{Conclusion}

Based on the explanation above, it was concluded that the obstruction of public services in the district of the island due to the physical state of the archipelago were geographically challenging, inadequate means of transportation, authority was not shared partially to the Head of District, and the coordination of district function was not running well. To optimize the implementation of public services at the district that was characterized as islands, an asymmetric decentralization with affirmative action was necessary for the specific autonomy of the island areas. The policies were intended for unbiased granting status or a different position and authority to the District institutions on the islands. Thus the role and function of districts in the area characterized by islands could be optimized in the public service. 


\section{References}

Cheema, G Shabbir., and Rondinelli, Dennis A. From Government Decentralization to Decentralized Governance, in Cheema, G. Shabbir., and Rondinelli, Dennis A (Ed). (2007). Decentralizing Governance: Emerging Concepts and Practices. Washington D.C: Brooking Institution Press.

Congleton, Roger D. (2006). Asymmetric Federalism and the Political Economy of Decentralization. Virginia: George Mason University.

Huda, Ni'matul. (2014). Desentralisasi Asimetris dalam NKRI: Kajian terhadap Daerah Istimewa, Daerah Khusus dan Otonomi Khusus. Bandung: Nusa Media.

Katorobo, James. (2007). Decentralization and Local Autonomy for Participatory Democracy, in Public Administration and Democratic Governance, Governments serving Citizens: Economic \& Social Affairs, United Nations, Januari, 2007.

Keban, Yeremias T. (2008). Enam Dimensi Strategis IImu Administrasi: Konsep, Teori dan Isu. [2nd Ed]. Yogyakarta: Gaya Media.

Niswaty, Risma., Mano, Johanna., and Akib, Haedar. (2015). An Analysis of the Public Service Performance Based on Human Development Index in Makassar City, Indonesia. International Journal Applied Business and Economic Research, 13(6), pp. 4395-4403.

Rondinelli, Dennis A. (1983). Implementing Decentralization Programmes in Asia: A Comparative Analysis. Public Administration and Development, 3, pp. 181-207.

Stacey White. (2011). Government Decentralization in the 21st Century, A Literature Review: A Report of the CSIS Program and Crisis, Conflict and Cooperation, CSIS, Washington, DC, December.

Syafiie, Inu Kencana. (1998). Ekologi Pemerintahan. Jakarta: PT. Pertja.

Siombo, Marhaeni Ria. (2010). Hukum Perikanan Nasional dan Internasional. Jakarta: Gramedia.

Tarlton, Charles D. (1965). Symmetry and Asymmetry as Elements of Federalism: A Theoretical Speculation. The Journal of Politics, 27(4).

Veljanovski, Aleksandra Maksimovska. (2010). The Model of the Asymmetric Fiscal Decentralisation in the Theory and The Case of Republic of Macedonia. Iustinianus Primus Law Review, 1(1).

Watts, Ronald L. (2005). A Comparative Perspective on Asymmetry in Federations, Asymmetry Series, 2005 (4), Institute of Intergovernmental Relations, Queen's University. 
ISSN 2039-2117 (online)

ISSN 2039-9340 (print)
Mediterranean Journal of Social Sciences MCSER Publishing, Rome-Italy
Vol 8 No 2

March 2017 